\title{
PENGEMBANGAN MEDIA PEMBELAJARAN MATEMATIKA INTERAKTIF ONLINE CLASSFLOW BERBANTUAN SOFTWARE GEOGEBRA PADA MATERI INTEGRAL LUAS DAERAH
}

\author{
Yuris Mimbadri, Suharto, Ervin Oktavianingtyas \\ Universitas Jember, Jl. Kalimantan 37, Jember \\ yurismimbadri@gmail.com
}

\begin{abstract}
Abstrak
Tujuan dari penelitian ini adalah untuk mendeskripsikan proses dan hasil pengembangan media pembelajaran untuk peserta didik SMA Kelas XI materi integral luas daerah berbantuan software GeoGebra. Jenis penelitian ini adalah penelitian pengembangan dan menggunakan model Thiagarajan. Uji coba dilakukan pada 31 peserta didik kelas XI di SMAN 1 Jember. Hasil penelitian ini menunjukkan koefisien korelasi sebesar 0,91 dengan kategori valid ditafsirkan "sangat tinggi" dengan menggunakan uji validitas, uji kepraktisan menunjukkan persentase sebesar 92,64\% yang berarti kategori "sangat baik" dengan penggunaan angket respon peserta didik, dan tes efektif menunjukkan hasil $80,65 \%$ atau 25 dari 31 peserta didik mendapatkan nilai diatas KKM dengan kategori "Baik". Berdasarkan hasil analisis data, dapat disimpulkan bahwa media pembelajaran matematika interaktif online ClassFlow berbantuan software GeoGebra pada materi integral luas daerah memenuhi kriteria valid, praktis dan efektif dan dapat untuk digunakan dalam pembelajaran matematika.
\end{abstract}

Kata Kunci: Pengembangan, GeoGebra, ClassFlow, Integral Luas Daerah.

\begin{abstract}
The purpose of this research was to describe the process and results of the development of learning media for high school students of Class XI regional integral material assisted by GeoGebra software. This type of research is the research on the development and use of the Thiagarajan model. The trial was conducted on 31 students of class XI at SMAN 1 Jember. The results of this study indicate a correlation coefficient of 0.91 with a valid category is asked "very high" by using validity test, practicality test shows a percentage of $92.64 \%$ which means the category "very good" with the use of questionnaires, student responses, and effective tests the results of $80.65 \%$ or 25 out of 31 students get scores according to the KKM in the category "Good". Based on the results of data analysis, it can be concluded that The Development of Online Interactive Mathematics Learning Media ClassFlow Assisted by GeoGebra Software on Area Integral that meets the requirements, valid and practical and can be used for use in mathematics learning
\end{abstract}

Keywords: Development, GeoGebra, ClassFlow, Area Integral.

\section{Pendahuluan}

Pembelajaran matematika merupakan proses pembelajaran yang direncanakan untuk mengembangkan dan meningkatkan kreatifitas berfikir siswa serta meningkatkan kemampuan konsentrasi terhadap materi matematika sebagai upaya meningkatkan penguasaan yang baik (Zubaidah, 2016). Tetapi, fakta yang terjadi di lapangan menunjukkan 
bahwa peserta didik secara keseluruhan belum mampu mengembangkan daya nalarnya dalam suatu proses pembelajaran matematika (Murtikusuma. 2015). Rendahnya hasil belajar matematika siswa diduga disebabkan oleh kesulitan memahami matematika, Dengan keterbatasan yang dimiliki, seringkali kemampuan berpikir peserta didik kurang mampu dalam menangkap dan menanggapi hal-hal yang bersifat abstrak atau yang belum pernah terekam dalam ingatannya.

Salah satu usaha untuk meningkatkan hasil belajar peserta didik yaitu dengan penggunaan strategi pembelajaran yang efektif. Mengajarkan disiplin ilmu pada peserta didik sangat dianjurkan, sehingga terjadi apa yang dinamakan dengan transfer of training yaitu pemahaman terhadap struktur keilmuan yang menyebabkan bahan pelajaran menjadi lebih komprehensif (Soviawati, 2011). Pembelajaran suatu pengetahuan dimana pengetahuan diwujudkan dalam bentuk visual imaginery, gambar, atau diagram, yang menggambarkan kegiatan kongkret. Untuk menjembatani proses belajar mengajar yang demikian, diperlukan media pembelajaran yang dapat memperjelas dan mempermudah peserta didik dalam menangkap materi yang disampaikan secara visual.

Penggunaan media pembelajaran berbasis teknologi informasi dalam proses belajar mengajar dapat membangkitkan keinginan, minat, motivasi, dan rangsangan belajar. Media pembelajaran akan membantu keefektifan pembelajaran dalam menyampaikan isi materi (Arsyad, 2003). Media pembelajaran atau bahan ajar merupakan komponen pembelajaran yang membantu mencapai tujuan sistem pembelajaran. Penggunaan media pembelajaran yang tepat dan menarik dapat mendorong motivasi belajar peserta didik, sehingga dapat meningkatakan hasil belajar peserta didik (Murtikusuma dkk, 2018)

Bagaimanapun proses pembelajaran tidak dapat terlepas dari keberadaan dan penggunaan teknologi. Pada saat ini perkembangan teknologi memasuki revolusi industri keempat yang lebih dikenal dengan revolusi industri 4.0 (Kusumaningtyas, 2018). Industri 4.0 bukan hanya teknologi, karena sumber daya manusia justru menjadi sangat penting, dengan alasan tersebut pendidikan harus berubah dari era Education 3.0 ke era Education 4.0 yang mengkombinasikan dunia nyata dan dunia maya untuk mengembangkan pengetahuan dan keterampilan peserta didik secara berkelanjutan seumur hidupnya (Sidiq, 2019). Revolusi ini dimulai dengan revolusi internet pada tahun 90-an yang ditandai dengan munculnya internet of thing dimana segala sesuatu berbasis digital. Pada revolusi ini, segala sesuatu menjadi tanpa batas dengan daya komputasi serta data yang tidak terbatas. Seiring dengan perkembangan zaman dan era globalisasi dengan ditandai pesatnya produk dan 
pemanfaatan teknologi informasi, maka konsepsi penyelenggaraan pembelajaran telah bergeser pada upaya perwujudan pembelajaran modern. Hal ini menuntut kemampuan, pengetahuan, dan kearifan pendidik untuk memilih dan memilah informasi yang benar-benar bermanfaat bagi kepentingan proses pembelajaran. Konsep-konsep pembelajaran modern diharapkan mampu menggabungkan produk dari kelompok-kelompok software intellegence dan hardware intellegence dalam dunia pembelajaran.

Inovasi yang dapat guru gunakan untuk merespons revolusi industri 4.0 adalah penggunaan media pembelajaran berbasis teknologi seperti pembelajaran interaktif online dalam matematika (Oktavianingtyas, 2018). E-Learning (electronic learning) dapat meningkatkan interaksi pembelajaran antara guru dengan peserta didik dan memungkinkan terjadinya interaksi pembelajaran kapan dan dari mana saja (time and place flexibility) (Fachri, 2006). E-Learning juga dapat menjangkau peserta didik dalam cakupan yang luas (potential to reach a global audience), dengan fleksibilitas waktu dan tempat, maka jumlah peserta didik yang dapat dijangkau melalui kegiatan pembelajaran elektronik semakin lebih banyak (Anggoro, 2001)

Salah satu e-Learning yang dapat digunakan dalam pembelajaran yaitu ClassFlow. ClassFlow adalah sistem pengiriman pelajaran interaktif yang meningkatkan kedalaman keterlibatan peserta didik dan guru dengan menyediakan penggunaan kolaboratif perangkat kelas, kurikulum digital dan penilaian untuk pembelajaran (Promethean, 2014) dan (Ramirez, 2017). Penggunaan ClassFlow dalam pembelajaran tidak perlu rumit dalam pemasangan. Selain itu, ClassFlow dapat digunakan secara gratis oleh siapa saja, dengan akses dan desain yang mudah. Selain itu, ClassFlow tidak hanya dapat diakses melalui komputer saja, juga dapat diakses melalui tablet dan smartphone yang dilengkapi oleh aplikasi browser, seperti Mozilla Firefox, Google Chrome, Explorer, dll.

Keunggulan dari ClassFlow ini yakni telah menyediakan fasilitas pembuatan media pembelajaran khusus guru berupa Create Quiz or Assessment dan Create Lesson. Selain itu kemasan quiz yang beragam, berupa pilihan ganda, benar/salah, yes/no, skala likert, jawaban singkat, dan uraian. Terdapat juga fitur chattingroom antara guru dan peserta didik ataupun peserta didik dan peserta didik. Semua kegiatan yang dilakukan oleh pengguna media pembelajaran dapat dilihat oleh guru pada akunnya. Penyampaian pembelajaran yang dinamis dari Classflow dan dapat dihubungkan langsung dari akun Google Drive pada fitur Resources atau sumber daya. ClassFlow mendukung semua sumber daya, termasuk ActivInspire, Flipcharts, presentasi PowerPoint ${ }^{\circledR}$, file SMART Notebook, file PDF, dan 
lainnya untuk menyusun pelajaran. Terdapat juga fitur Market Place yang berisi macammacam permainan seperti, teka-teki silang, permainan ingatan, permainan mencocokkan, flash card, dan lain-lainnya.

GeoGebra merupakan salah satu program komputer yang dapat dimanfaatkan sebagai media pembelajaran matematika. Software GeoGebra merupakan sebuah aplikasi yang dapat diakses secara gratis untuk belajar geometri, aljabar, dan kalkulus pada tingkat pembelajaran dan kelas yang berbeda (Arbain, 2015) dan . GeoGebra ini dibuat untuk memenuhi kaidah-kaidah pembelajaran matematika yang berkualitas. Hal tersebut dapat dilihat pada tampilannya yang terdiri dari tiga jendela: jendela analitik (aljabar), jendela grafis (visual), dan jendela numerik (spreadsheet). Dengan beragam fasiltas yang dimiliki, GeoGebra dapat dimanfaatkan sebagai media pembelajaran matematika untuk mendemonstrasikan atau memvisualisasikan konsep-konsep geometri, serta sebagai alat bantu untuk mempermudah peserta didik dalam mengkonstruksi konsep-konsep geometri pada pokok bahasan integral luas daerah.

Program GeoGebra merupakan program yang cukup efektif dan praktis untuk membantu menvisualisasikan objek-objek matematika khususnya pada materi fungsi dan grafik (Fatoni, 2017). Pemanfaatan program GeoGebra memberikan beberapa keuntungan, di antaranya adalah sebagai berikut. 1) Lukisan-lukisan geometri yang biasanya dihasilkan dengan cepat dan teliti dibandingkan dengan menggunakan pensil, penggaris, atau jangka. 2) adanya fasilitas animasi dan gerakan-gerakan manipulasi (dragging) pada program GeoGebra dapat memberikan pengalaman visual yang lebih jelas kepada peserta didik dalam memahami konsep geometri. 3) Dapat dimanfaatkan sebagai balikan/evaluasi untuk memastikan bahwa lukisan yang telah dibuat benar. 4) Mempermudah guru/peserta didik untuk menyelidiki atau menunjukkan sifat-sifat yang berlaku pada suatu objek geometri (Mahmudi, 2010).

\section{Metode Penelitian}

Model pengembangan yang digunakan adalah model Thiagarajan. Model pengembangan yang digunakan dalam penelitian ini adalah model Thiagarajan. Model Thiagarajan terdiri dari empat tahap yang dikenal dengan model 4-D (four D Model). Keempat tahap tersebut adalah tahap pendefinisian (define), tahap perancangan (design), tahap pengembangan (develop), tahap penyebaran (disseminate). 1) Tahap pendefinisian bertujuan untuk menentukan dan menetapkan kebutuhan dalam pembelajaran dengan menganalisis tujuan 
dan memperhatikan batasan materi, 2) Tahap perancangan meliputi pemilihan media, pemilihan format, rancangan awal media, dan penyusunan tes, 3) Tahapan pengembangan ini bertujuan untuk menghasilkan produk atau media pembelajaran yang telah direvisi, uji coba terhadap peserta didik SMAN 1 Jember kelas XI MIPA 6, 4) Tahap penyebaran dalam penelitian ini dilakukan di SMAN 1 Jember dan menyebarkan melalui media sosial dan web. Analisis data yang digunakan yaitu kevalidan berdasarkan validasi dari para ahli, kepraktisan dianalisis berdasarkan angket respon pengguna, dan keefektifan berdasarkan hasil tes peserta didik.

\section{Hasil dan Pembahasan}

Hasil penelitian ini melalui proses pengembangan media dengan menggunakan model pengembangan penelitian Thiagarajan atau 4-D model yang terdiri dari empat tahapan yaitu tahap pendefinisian (define), tahap perancangan (design), tahap pengembangan (develop), dan tahap penyebaran (disseminate). Langkah-langkah pembahasan penelitian pengembangan ini adalah sebagai berikut.

a) Tahap Pendefinisian (Define)

Pembelajaran matematika selama ini menggunakan pembelajaran manual, guru juga hanya menggunakan LCD proyektor sebagai alat bantu media pembelajaran, serta media yang digunakan hanya berupa tampilan power point yang telah diunggah ke dalam $e$ Learning sekolah, permasalahan dasar dalam pengembangan media berdasarkan kurangnya kontribusi peserta didik dalam pembelajaran, serta kurangnya pemanfaatan fasilitas sekolah seperti jaringan internet dan laboratorium komputer. Tujuan pembelajaran dapat ditentukan berdasarkan analisis awal-akhir, analisis media, dan spesifikasi tujuan pembelajaran.

b) Tahap Perancangan (Design)

Tahap kedua ini merupakan proses merancang media pembelajaran yang sesuai dengan kajian permasalahan dasar di SMAN 1 Jember. Media yang digunakan yaitu media pembelajaran interaktif online menggunakan ClassFlow berbantuan software GeoGebra. Tahap perancangan meliputi pemilihan media, pemilihan format, perancangan awal media dan penyusunan tes pada media pembelajaran. Tampilan media GeoGebra dan kelas online ClassFlow dapat dilihat pada gambar berikut. 


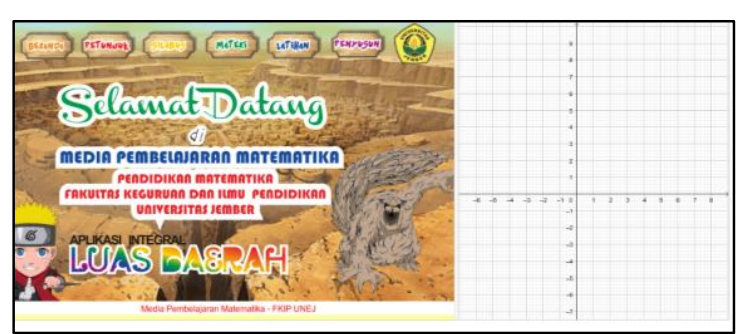

(a) Beranda

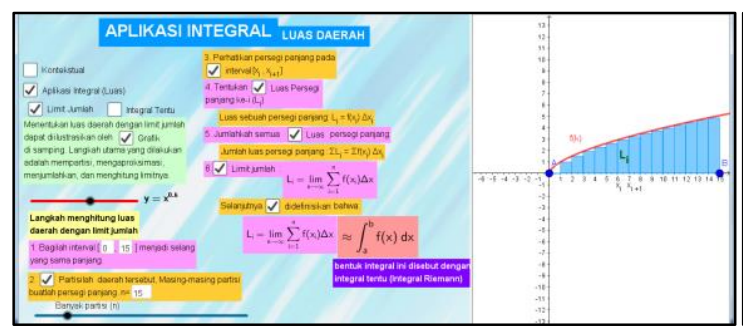

(c) Materi

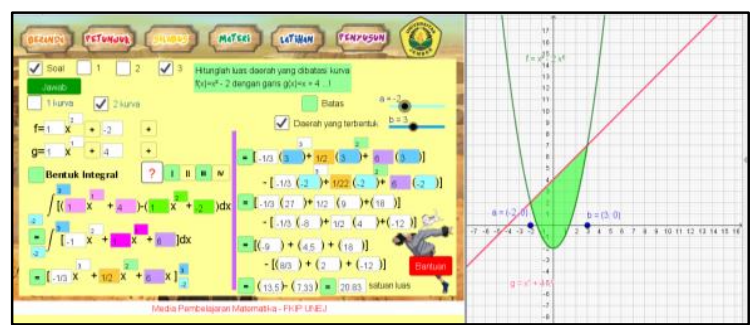

(e) Latihan soal

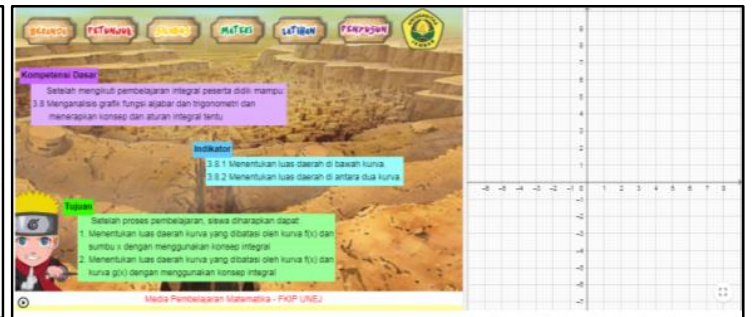

(b) Silabus

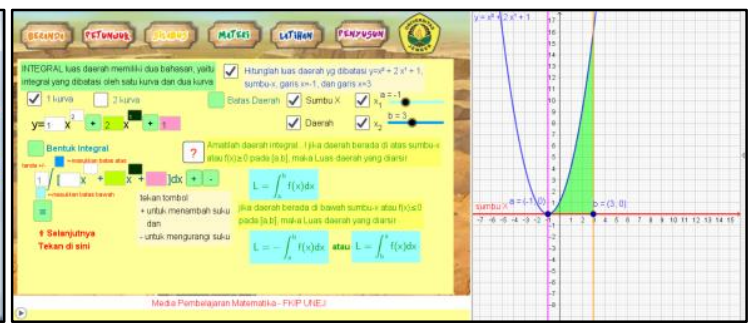

(d) Materi

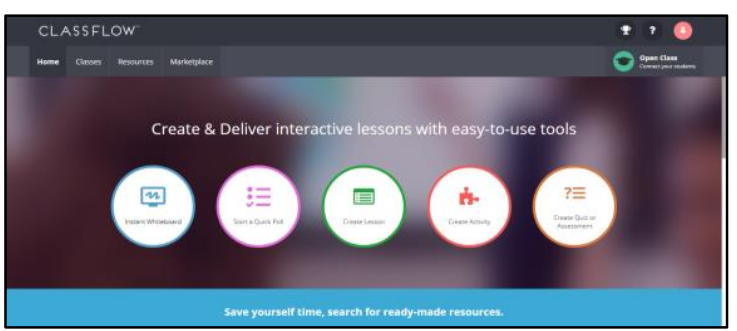

(f) ClassFlow

Gambar 1. Tampilan Media GeoGebra dan e-Learning Class Flow

\section{c) Tahap Pengembangan (Develop)}

Tahap pengembangan media pembelajaran interaktif online ini dilakukan dengan menghasilkan Draf I berupa Applet GeoGebra yang telah diunggah pada GeoGebra online dan ditautkan pada ClassFlow, kemudian divalidasi oleh tiga validator untuk memperoleh data penilaian yang terdapat pada lembar validasi media yang diberikan. Berdasarkan hasil analisis data menunjukkan bahwa nilai koefisien korelasi pengembangan media pembelajaran ini sebesar 0,91 termasuk kategori "Sangat Tinggi", sehingga dapat disimpulkan bahwa media pembelajaran ini valid. Hasil validasi dapat dilihat pada Gambar 2. 


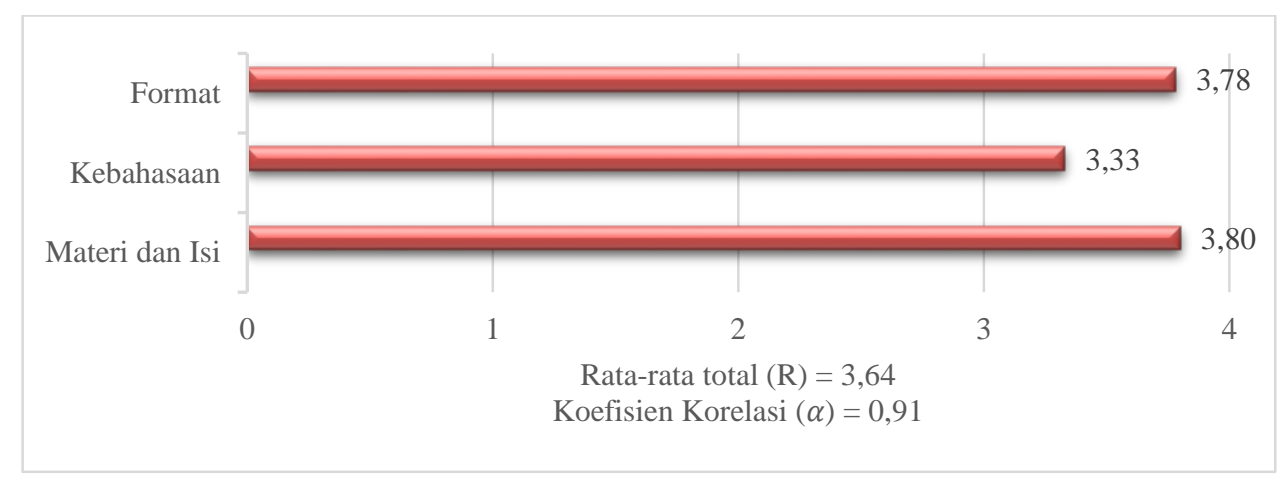

Gambar 2. Hasil Validasi

Setelah Penilaian hasil validasi oleh para validator terhadap media pembelajaran menunjukkan nilai lebih besar dari 0,6 sesuai dengan kriteria interpretasi kevalidan media, maka media pembelajaran matematika layak untuk dilakukan uji coba di SMAN 1 Jember. Uji coba dilaksanakan dengan kegiatan pengenalan media pembelajaran, pembuatan akun ClassFlow peserta didik, dan pembelajaran materi integral luas daerah dan kegiatan latihan soal berbantuan GeoGebra, mengerjakan tes hasil belajar, dan pengisian angket respon. Data dari hasil uji coba digunakan untuk menganalisis kepraktisan dan keefektifan media. Kepraktisan media dianalisis berdasarkan angket respon pengguna setelah menggunakan media selama pembelajaran, sedangkan keefektifan media dianalisis berdasarkan nilai tes hasil belajar peserta didik. Berdasarkan analisis angket respon pengguna media tersebut, diperoleh nilai presentase respon angket terhadap media pembelajaran yaitu 92,64\% termasuk kategori "Sangat Baik". Hal ini menunjukkan produk media pembelajaran ini memenuhi kriteria kepraktisan. Hasil data angket respon pengguna dapat dilihat pada Gambar 4.

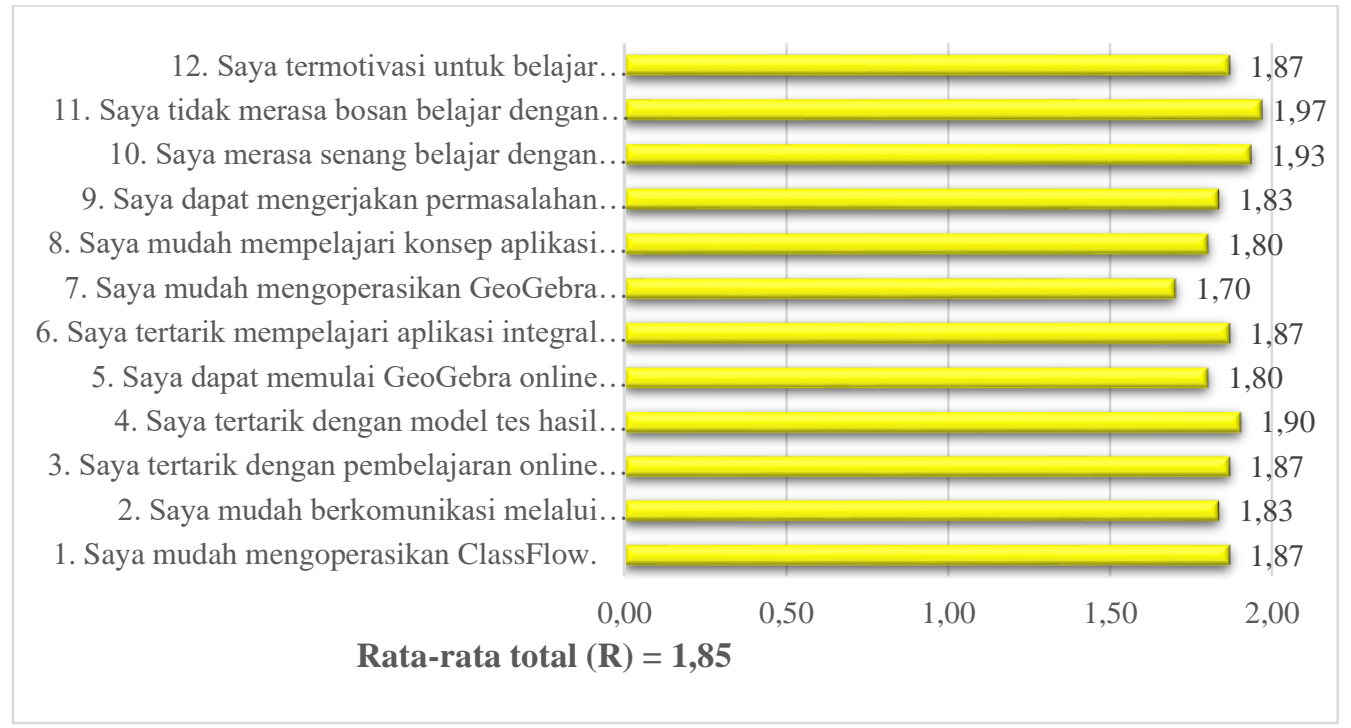

Gambar 3. Hasil Angket Respon Pengguna Media 
Uji keefektifan dilakukan untuk mengetahui seberapa efektif media pembelajaran ini yang telah dikembangkan. Uji keefektifan dari media pembelajaran dilakukan dengan cara menganalisis hasil dari tes hasil belajar peserta didik yang bertujuan untuk mengukur pemahaman peserta didik terhadap materi yang disajikan dengan bantuan media pembelajaran GeoGebra. Tes hasil belajar terdiri dari 10 soal meliputi 4 pilihan ganda, 3 jawaban singkat, dan 3 benar/salah yang harus dikerjakan oleh peserta didik. Media pembelajaran dapat dikatakan efektif apabila lebih dari atau sama dengan $80 \%$ dari seluruh objek uji coba memenuhi kriteria ketuntasan minimal (KKM), dimana KKM di SMAN 1 Jember yaitu 76. Hasil tes belajar peserta didik diperoleh persentase ketuntasan dalam kelas sebesar 80,65\% atau 25 dari 31 peserta didik. Berdasarkan hal tersebut maka media pembelajaran dalam penelitian ini dapat dikatakan efektif. Hasil tes yang diperoleh peserta didik dapat dilihat pada Gambar 6.

\section{Nilai Tes Hasil Belajar}

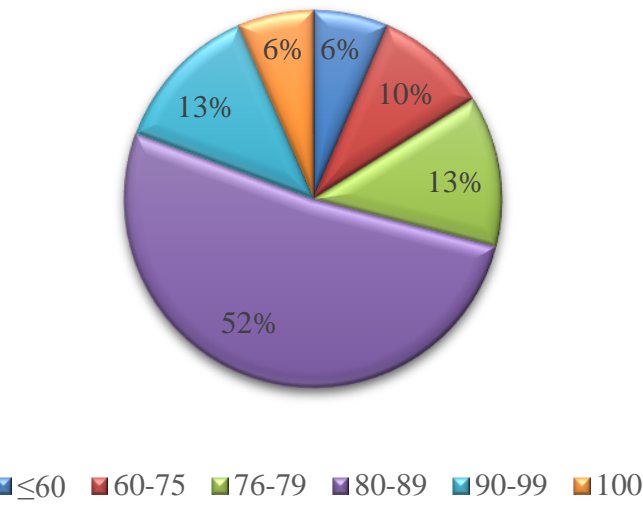

Gambar 4. Nilai Tes Hasil Belajar

d) Tahap Penyebaran (Disseminate)

Tahap penyebaran dilakukan di SMAN 1 Jember dan juga melalui media sosial. Tahap penyebaran di SMAN 1 Jember dimulai terhadap guru, yaitu berupa pemberian softcopy rancangan media pembelajaran GeoGebra dan buku panduan media pembelajaran. Untuk penyebaran yang dilakukan di media sosial yaitu melalui Facebook, Instagram, YouTube, dan web dengan laman https://yurismeup.blogspot.com/2019/07/media-pembelajaran-matematika.html.

Selain itu, media ini disebar luaskan dengan bantuan guru matematika SMAN 1 Jember melalui grup MGMP guru matematika di Jember. 


\section{Simpulan dan Saran}

Pengembangan media pembelajaran matematika interaktif online menggunakan ClassFlow berbantuan software GeoGebra pada materi integral luas daerah memenuhi kriteria valid, praktis dan efektif. Tingkat kevalidan berdasarkan penilaian validator sebesar 0,91 dengan kategori "Sangat Tinggi"; Tingkat kepraktisan berdasarkan angket respon pengguna sebesar 92,64\% dengan kategori "Sangat Baik"; dan Tingkat keefektifan berdasarkan nilai tes hasil belajar peserta didik di atas KKM yaitu sebesar 80,65\% atau 25 dari 31 peserta didik dengan kategori "Baik"

Berdasarkan hasil penelitian ini, saran yang dapat diberikan adalah Untuk peneliti yang akan mengembangkan penelitian menggunakan ClassFlow atau software GeoGebra dapat menggunakan skripsi ini sebagai referensi dalam penelitiannya. Kesulitan berada pada pembuatan media, yaitu pembuatan integral luas daerah terhadap sumbu Y, karena coding integral luas daerah pada GeoGebra hanya dapat mengoperasikan terhadap sumbu X. Hendaknya untuk peneliti lain dapat menyempurnakan media ini dengan menambahkan luas integral terhadap sumbu Y. Selain itu, dalam membuat fitur-fitur yang mengacu pada objek berupa gambar (slider) hendaknya lebih memperhatikan gambar luas daerah, jangan sampai melebihi batas layar tampilan dari GeoGebra.

Untuk peneliti yang akan menggunakan ClassFlow hendaknya memanfaatkan semua fitur yang ada, seperti pemanfaatan fitur Instan Whiteboard, Quick Poll Create Lesson, dan Create Activity. Serta Fitur Create Quiz yang dapat digunakan untuk memperoleh data seperti angket respon pengguna dengan memanfaatkan tipe soal Skala Likert. Guru dan sekolah dapat menjadikan media pembelajaran ini sebagai bahan ajar peserta didik pada materi integral luas daerah. Diharapkan dengan adanya media ini peserta didik lebih mudah untuk memahami materi integral luas daerah.

Tidak lupa penulis ucapkan terimakasih kepada semua pihak yang telah membantu dalam penyusunan dan pempublikasian artikel ini. Penulis juga menerima segala kritik dan saran yang membangun dari semua pihak. Akhirnya penulis berharap, semoga artikel ini dapat bermanfaat.

\section{Referensi}

Anggoro, M. Toha. 2001. "Tutorial Elektronik melalui Internet dan Fax Internet”. Jurnal Pendidikan, vol. 2, no. 1, pp. Tangerang: Universitas Terbuka.

Arbain, N. dan Shukor, N. A. 2015. The effects of GeoGebra on students' achievement. Procedia - Social and Behavioral Sciences, 172: 208 - 214. 
Arsyad, A. 2003. Media Pembelajaran. Jakarta: PT Raja Grafindo Persada.

Fachri, M. 2006.“E-Learning Sebagai Alternatif Pembelajaran Modern”. Jurnal Pendidikan Inovatif, vol. 2, no. 1, pp. 40-46.

Fatoni, M. Faizal. 2017. "Pengembangan Media Pembelajara Interaktif Online Menggunakan Kelaskita Berbantuan Software Geogebra Pada Materi Persamaan Kuadrat". Kadigma, vol. 8, no. 2, pp. 24-33.

Kusumaningtyas, N., D. Trapsilasiwi, and A. Fatahillah, 2018. "Pengembangan Media Pembelajaran Interaktif Online Berbantuan Desmos Pada Kelaskita Materi Program Linier Kelas XI SMA,” Kadigma, vol. 9, pp. 118-128.

Mahmudi, A. 2010. Membelajarkan Geometri dengan Program GeoGebra. Makalah dipresentasikan dalam Seminar Nasional Matematika dan Pendidikan Matematika Jurusan Pendidikan Matematika FMIPA UNY. http://eprints.uny.ac.id/10483/1/P6Ali\%20M.pdf [diakses 27 November 2018].

Murtikusuma, R. P. 2015. "Pengembangan Perangkat Pembelajaran Matematika Model Problem-Based Learning Berbantuan Media Powerpoint untuk Siswa Kelas XI SMK Materi Barisan dan Deret", Saintifika, vol. 17, no. 2, pp. 20-33.

Murtikusuma, R. P., A. Fatahillah, E. Oktavianingtyas, S. Hussen, and N. Lailiya, 2019. "The development of interactive mathematics learning media based on schoology and visual basic through industrial revolution 4.0," IOP Conf. Ser. Earth Environ. Sci., vol. 243, no. 1, pp. 0-6.

Oktavianingtyas, E., F. S. Salama, A. Fatahillah, L. A. Monalisa, and T. B. Setiawan. 2018. "Development 3D Animated Story as Interactive Learning Media with Lectora Inspire and Plotagon on Direct and Inverse Proportion Subject," J. Phys. Conf. Ser., vol. 1108, no. 1 ,

Promethean World, 2014. "ClassFlow," [Online]. Available: https://www.prometheanworld.com/gb/products/lesson-delivery-software/classflow/. [Accessed: 21-Nov-2018].

Ramirez, C. P. and M. G. Andres. 2017. "Educational Apps and Learning Based Platforms and Its Pedagogical Use From Primary To Higher Levels," Congr. Int. Innovación Educ. en Edif., no. March.

Sidiq, M., Zulfiati, M. Hartati, Suyitno, and B. Endry, 2019. "Media Pembelajaran Matematika Menyongsong Industry 4.0: Tinjauan literatur sistematis untuk analisis kebutuhan," January.

Soviawati, E. 2011. "Pendekatan Matematika Realistik (PMR) untuk Meningkatkan Kemampuan Berfikir Siswa di Tingkat Sekolah Dasar". Jurnal Khusus, vol. 1, no. 2, pp. 79-85.

Zubaidah, A. R. 2016. Pembelajaran Matematika. Yogyakarta: Aswa Pressindo. 